\title{
Correction to: Quantification of visual inducement of knots by eye- tracking
}

\author{
Masashi Nakamura ${ }^{1} \cdot$ Takayuki Kondo $^{1}$
}

Published online: 23 November 2018

(c) The Author(s) 2018

\section{Correction to: J Wood Sci (2008) 54:22-27 https://doi.org/10.1007/s10086-007-0910-z}

The article Quantification of visual inducement of knots by eye-tracking, written by Masashi Nakamura and Takayuki Kondo, was originally published electronically on the publisher's internet portal (currently SpringerLink) on 19 October, 2007 without open access. With the author(s)' decision to opt for Open Choice the copyright of the article changed on 20 November, 2018 to $\odot$ The Author(s) 2018 and the article is forthwith distributed under the terms of the Creative Commons Attribution 4.0 International License (http:// creativecommons.org/licenses/by/4.0/), which permits use, duplication, adaptation, distribution and reproduction in any medium or format, as long as you give appropriate credit to the original author(s) and the source, provide a link to the Creative Commons license and indicate if changes were made.

Open Access This article is distributed under the terms of the Creative Commons Attribution 4.0 International License (http://creativeco mmons.org/licenses/by/4.0/), which permits unrestricted use, distribution, and reproduction in any medium, provided you give appropriate credit to the original author(s) and the source, provide a link to the Creative Commons license, and indicate if changes were made.
The original article can be found online at https://doi.org/10.1007/ s10086-007-0910-z.

Masashi Nakamura

nakamasa@kais.kyoto-u.ac.jp

1 Graduate School of Agriculture, Kyoto University, Kitashirakawa Oiwake-cho, Sakyo-ku, Kyoto 606-8502, Japan 